V. Letsoin, Pengakuan Tandatangan Pada ......................

Jurnal Sasi Vol.16. No.3 Bulan Juli - September 2010

\title{
PENGAKUAN TANDATANGAN PADA DOKUMEN ELEKTRONIK DALAM PEMBUKTIAN HUKUM ACARA PERDATA DI INDONESIA
}

\author{
Oleh : V. Letsoin
}

\begin{abstract}
The use of an electronic signature on an electronic document may guarantee he security of an electronic information message, using public network, because the electronic is created based on the asymmetric cryptography technology. From the research, there are some opinion disagreements concerning the authentication power of electronic documents signed with electronic signatures, used as prof in the court. The government should immediately legalized the Government Ordinance concerning Electronic Signature and Government Ordinance concerning Electronic Signature and Government Ordinance concerning Electronic Certification, there will be a through legal regulation of the Act Number 11 Year 2008.
\end{abstract}

Keywords : electronic documents, signature, proof, authentication.

\section{A. PENDAHULUAN}

Semakin pesatnya perkembangan teknologi informasi dan telekomunikasi, telah mengakibatkan semakin beragamnya pula aneka jasa-jasa (features) fasilitas telekomunikasi yang ada, serta semakin canggihnya produk-produk teknologi informasi yang mampu mengintegrasikan semua media informasi. (Arrianto Mukti Wibowo,1999 :3)

Komputer sebagai alat bantu manusia dengan didukung perkembangan teknologi informasi, telah membantu akses ke dalam jaringan-jaringan public (public network) dalam melakukan pemindahan data dan informasi, dengan kemampuan komputer dan akses yang semakin berkembang, maka transaksi perdagangan pun dilakukan di dalam jaringan komunikasi tersebut. Jaringan public mempunyai keunggulan dibandingkan dengan jaringan privat dengan adanya efisiensi biaya dan waktu, hal ini membuat perdagangan dengan transaksi elektronik (electronic Commerce) menjadi pilihan bagi para pelaku bisnis untuk melancarkan transaksi perdagangannya, karena sifat jaringan publik yang mudah untuk diakses oleh setiap orang ataupun perusahaan yang dilaksanakan dengan sistem elektronik. Sistem elektronik, digunakan untuk menjelaskan keberadaan sistem informasi yang merupakan penerapan teknologi informasi yang berbasis jaringan telekomunikasi dan media elektronik, yang berfungsi merancang, memproses, menganalisis, menampilkan, dan mengirimkan atau menyebarkan informasi elektronik. Sistem informasi secara teknis dan manajemen, sebenarnya adalah perwujudan penerapan produk teknologi informasi ke dalam suatu bentuk organisasi dan manajemen sesuai dengan karakteristik kebutuhan pada organisasi tersebut dan sesuai dengan tujuan peruntukkannya. Pada sisi lain, sistem informasi secara teknis dan fungsional adalah keterpaduan sistem antara manusia dan mesin, yang mencakup 
komponen perangkat keras, perangkat lunak, prosedur, sumber daya manusia, dan substansi informasi yang dalam pemanfaatanya mencakup fungsi input, process, output, storage, dan communication. ${ }^{1}$

Setiap orang dapat memberikan informasi tentang segala hal, termasuk juga pemberian informasi terhadap penjualan suatu barang atau jasa dengan menggunakan teknologi informasi ini, dari informasi tersebut, apabila seseorang tertarik untuk memiliki suatu produk barang atau jasa yang ditawarkan tersebut, maka akan terjadi suatu transaksi elektronik. Transaksi elektronik bersifat non face (tanpa bertatap muka), non sign (tidak memakai tanda tangan asli) dan tanpa batas wilayah (seseorang dapat melakukan transaksi elektronik dengan pihak lain walaupun mereka berada di Negara yang berbeda) dengan menggunakan teknologi informasi.

Dalam perkembangannya, aspek keamanan dalam informasi sudah mulai diperhatikan. Ketika informasi ini menjadi rusak atau maka akan terdapat resiko-resiko yang harus ditanggung oleh orang-orang baik yang mengirim, membutuhkan, ataupun sekedar melihatnya, dikarenakan penggunaan informasi elektronik ini, menggunakan jaringan publik, dimana setiap orang dapat mengetahui informasi elektronik tersebut, atau apabila salah satu pihak tidak melaksanakan prestasi dari transaksi elektronik yang telah disepakati dengan pihak yang lain, hal ini merugikan pihak yang berkepentingan yang menggunakan teknologi informasi untuk penjualan suatu barang atau jasa.

Teknologi-teknologi dan media-media baru semakin luas dipergunakan dalam praktek perdagangan, baik di tingkat nasional maupun internasional, sehingga Organisasi-

1 lihat Penjelasan Undang-Undang Nomor 11 Tahun 2004 Tentang Informasi dan Transaksi Elektronik organisasi Internasional semakin memikirkan pengakuan hukum terhadap dokumen elektronik dan tanda tangan elektronik. Akhirnya, dorongan datang dari Komisi Perserikatan Bangsa-Bangsa untuk Hukum Dagang Internasional United Nations Commission On International Trade Law, Model Law on Elektronic Commerce (selanjutnya disebut UNCITRAL), mengeluarkan UNCITRAL Model Law on Electronic Commerce pada tanggal 16 Desember 1996.

Kegiatan cyber tidak lagi sederhana, karena kegiatannya tidak lagi dibatasi oleh teritorial suatu negara, yang mudah diakses kapanpun dan dari manapun. Kerugian dapat terjadi, baik pada pelaku transaksi maupun pada orang lain yang tidak pernah melakukan transaksi. Di samping itu, pembuktian merupakan faktor yang sangat penting, mengingat informasi elektronik bukan saja belum terakomodasi dalam sistem hukum acara Indonesia secara komprehensif, melainkan juga ternyata sangat mudah untuk dipalsukan, dan dikirim ke berbagai penjuru dunia dalam waktu hitungan detik. Dengan demikian, dampak yang diakibatkannya pun bisa demikian kompleks dan rumit.

Sejak tahun 1999 Rancangan UndangUndang ini dibahas oleh Badan Legislatif yang berwenang, akhirnya Indonesia mempunyai aturan hukum untuk mengatur masalah tersebut dengan dikeluarkannya Undang-Undang Nomor 11 tahun 2008, tentang "Informasi dan Transaksi Elektronik" yang disahkan pada tanggal 21 April 2008.

Berdasarkan pada Pasal 18 jo Pasal 7 jo Pasal 11 Undang-Undang Nomor 11 Tahun 2008 maka kekuatan pembuktian dokumen elektronik tersebut yang ditandatangani dengan digital signature sama dengan kekuatan pembuktian akta otentik yang dibuat oleh pejabat umum yang berwenang.

Aturan tersebut diatas bertentangan dengan Pasal 1 ayat (7) Undang-Undang 
V. Letsoin, Pengakuan Tandatangan Pada ......................

Jurnal Sasi Vol.16. No.3 Bulan Juli - September 2010

Nomor 30 tahun 2004 yang dimaksud akta notaris adalah akta otentik yang dibuat oleh atau dihadapan Notaris menurut bentuk dan tata cara yang ditetapkan dalam UndangUndang ini. Sedangkan pengertian akta otentik berdasarkan Pasal 1868 KUH Perdata adalah suatu akta yang didalam bentuk yang ditentukan oleh Undang-Undang, dibuat oleh atau di hadapan pegawai-pegawai umum yang berkuasa untuk itu di tempat di mana akta dibuatnya.

Akibat terjadi suatu pertentangan aturan tersebut, maka apabila salah satu pihak mengajukan gugatan dengan alat bukti dokumen elektronik yang ditandatangani dengan tanda tangan elektronik sebagai alat bukti , maka di dalam menyelesaikan sengketa dipengadilan, hakim dituntut untuk berani melakukan terobosan hukum, karena dia yang paling berkuasa dalam memutuskan suatu perkara dan karena dia juga yang dapat memberi suatu vonnis van de rechter, yang tidak langsung dapat didasarkan atas suatu peraturan hukum tertulis atau tidak tertulis.

Dokumen elektronik yang ditandatangani dengan sebuah digital signature, dapat dikategorikan sebagai bukti tertulis. Tetapi, terdapat suatu prinsip hukum yang menyebabkan sulitnya pengembangan penggunaan dan dokumen elektronik atau digital signature, yakni adanya syarat bahwa dokumen tersebut harus dapat dilihat, dikirim dan disimpan dalam bentuk kertas.

Sehubungan dengan penulisan ini maka permasalahan yang muncul adalah Bagaimana pengakuan tanda tangan pada suatu dokumen elektronik di dalam pembuktian hukum acara perdata di Indonesia?

\section{B. PEMBAHASAN}

\section{Pengakuan Tanda Tangan Pada Suatu Dokumen Elektronik.}

$\begin{array}{ccr}\quad \text { Sistem } & \text { perdagangan } & \text { dengan } \\ \text { memanfaatkan } & \text { sarana } & \text { internet } \\ \text { (interconnection } & \text { networking), } & \text { yang }\end{array}$ selanjutnya disebut e-commerce telah mengubah wajah dunia bisnis Indonesia. Selain disebabkan oleh adanya perkembangan teknologi informasi, $e$ commerce lahir atas tuntunan masyarakat terhadap pelayanan yang serba cepat, mudah dan praktis. Melalui internet masyarakat memiliki ruang gerak yang lebih luas dalam memilih produk (barang dan jasa) yang akan dipergunakan tentunya dengan berbagai kualitas dan kuantitas sesuai yang diinginkan. E-commerce merupakan salah satu bentuk transaksi perdagangan yang paling banyak dipengaruhi oleh perkembangan teknologi informasi. Melalui transaksi perdagangan ini, konsep pasar tradisional (dimana penjual dan pembeli secara fisik bertemu) berubah menjadi konsep telemarketing (perdagangan jarak jauh dengan menggunakan internet). $E$ commerce pun telah mengubah cara pembeli dalam memperoleh produk yang diinginkan. (Albarda, 1987: 2)

Melalui e-commerce semua formalitas-formalitas yang biasa digunakan dalam transaksi konvensional dikurangi di samping tentunya pembelipun memiliki 44 Albarda, 1887, Sistim Informasi Untuk Kegiatan Promosi Dan Perdagangan, makalah pada seminar informasi ITB Bandung kemampuan untuk mengumpulkan dan membandingkan informasi seperti barang dan jasa secara lebih leluasa tanpa dibatasi oleh wilayah (bordeless). Perjanjian $e$ comerce yang dibuat oleh para pihak yang berkepentingan dalam bentuk dokumen elektronik, bila salah satu pihak melanggar kesepakatan tersebut atau wanprestasi dari salah satu pihak, maka pihak yang dirugikan dapat mengugat ke Pengadilan dengan alat bukti dokumen elektronik. Penyelesaian suatu sengketa tersebut atau kasus mutlak hanya menyadarkan pada keyakinan hakim 
V. Letsoin, Pengakuan Tandatangan Pada .....................

Jurnal Sasi Vol.16. No.3 Bulan Juli - September 2010

ini adalah hal yang sangat riskan karena dapat menimbulkan kekhawatiran bahwa keyakinan hakim tersebut akan bersifat subjektif, sehingga akan menimbulkan tindakan sewenang-wenang dari hakim yang justru tidak memberikan rasa keadilan bagi para pihak yang berperkara, maka sewajarnyalah apabila dalil-dalil yang dikemukakan para pihak yang bersengketa juga menjadi dasar pertimbangan bagi hakim agar dapat dicapai suatu keputusan yang objektif. Pembuktian merupakan satu aspek yang memegang peranan sentral dalam suatu proses peradilan. Pada kasus pidana, nasib terdakwa akan ditentukan padatahap ini, jika tidak cukup alat bukti, terdakwa akan dinyatakan tidak bersalah dan harus dibebaskan, begitupun sebaliknya. Sedangkan pada kasus perdata, dalam tahap pembuktian ini para pihak diberikan kesempatan untuk menunjukkan kebenaran terhadap fakta-fakta hukum yang merupakan titik pokok sengketa. Sehingga, hakim yang memeriksa dan memutus perkara akan mendasarkan pada alat bukti yang diajukan oleh para pihak yang bersengketa. (Zamrony, $2008: 1)$

Membuktikan adalah upaya untuk mengumpulkan fakta-fakta yang dapat dianalisis dari segi hukum dan berkaitan dengan suatu kasus yang digunakan untuk memberikan keyakinan hakim dalam mengambil keputusan, sedangkan pembuktian adalah proses untuk membuktikan suatu kasus yang disertai dengan fakta-fakta yang dapat dianalisis dari segi hukum untuk memberikan keyakinan hakim dalammengambil keputusan. (Ali Afandi, 2000 : 198).

\section{Kekuatan Pembuktian Dokumen Elektronik Dengan Tanda Tangan Elektronik Dalam Proses Persidangan Perdata}

Dokumen elektronik yang ditandatangani dengan tanda tangan elektronik didalam hukum pembuktian di Indonesia, diakui esensinya setelah diatur di dalam Undang-Undang Nomor 11 Tahun 2008 tentang Informasi dan Transaksi Elektronik bahwa informasi elektronik atau dokumen elektronik dan/atau hasil cetaknya merupakan alat bukti hukum yang sah, dan merupakan perluasan dari alat bukti yang sah sesuai dengan hukum acara yang berlaku di Indonesia hal tersebut berdasarkan ketentuan pada Pasal 5 ayat 2 Undang-Undang Nomor 11 Tahun 2008. Berdasarkan pada Pasal 164 HIR dan Pasal 284 RBg, alat-alat bukti yang sah terdiri dari bukti tulisan, bukti dengan saksi-saksi, persangkaan-persangkaan, pengakuan dan sumpah, sedangkan menurut Pasal 184 Kitab Undang-undang Hukum Acara Pidana, alat-alat bukti yang sah terdiri dari keterangan saksi, keterangan ahli, surat, petunjuk dan keterangan terdakwa. Oleh karena itu, alat bukti menurut hukum acara di atas yang dibuat dalam bentuk informasi elektronik/dokumen elektronik, dan informasi elektronik/dokumen elektronik itu sendiri, merupakan alat bukti yang sah menurut Undang-Undang Informasi dan Transaksi Elektronik. (Ario Juliano Gema,2008 : 2 )

Dokumen elektronik dinyatakan sah apabila menggunakan sistem pengaman yang dapat dipertanggungjawabkan sesuai dengan perkembangan teknologi informasi, serta memenuhi persyaratan minimum sebagai berikut :

a. dapat menampilkan kembali informasi dan/atau dokumen elektronik secara utuh sesuai dengan masa retensi yang ditetapkan dengan peraturan perundangundangan.

b. dapat melindungi ketersediaan, keutuhan, keotentikan, kerahasiaan, dan keteraksesan informasi elektronik dalam penyelenggaraan sistem elektronik tersebut; 
\begin{tabular}{r|r} 
V. Letsoin, Pengakuan Tandatangan Pada ..................... & 56 \\
Jurnal Sasi Vol.16. No.3 Bulan Juli - September 2010 &
\end{tabular}

c. dapat beroperasi sesuai dengan prosedur atau petunjuk dalam penyelenggaraan sistem elektronik tersebut;

d. dilengkapi dengan prosedur atau petunjuk yang diumumkan dengan bahasa, informasi, atau symbol yang dapat dipahami oleh pihak yang bersangkutan dengan penyelenggaraan sistem elektronik tersebut; dan

e. memiliki mekanisme yang berkelanjutan untuk menjaga kebaruan, kejelasan, dan kebertanggungjawaban prosedur atau petunjuk.

Dokumen elektronik merupakan dokumen yang terjadi akibat suatu transaksi komersial elektronik (e-commerce). Untuk menentukan kapan terjadinya kesepakatan dalam suatu transaksi komersial elektonik ( $e$ commrce). Menurut Hikmahanto Juwana, dokumen pada transaksi komersial elektronik (e-commerce) sudah berlaku secara sah dan mengikat pada saat pembeli mengklik tombol sent dan dalam hal ini pembeli dianggap telah sepakat serta menyetujui syarat dan kondisi yang tercantum dalam penawaran. Mengenai kapan terjadinya, kesepakatan ini, para pelaku transaksi komersial elektronik memberikan pendapat yang berbeda. Mia Lestari, mengatakan selama ini ia melakukan transaksi komersial elektronik dengan memanfaatkan website dan email. Lebih lanjut ia mengatakan bahwa kesepakatan terjadi pada saat calon pembeli menyetujui harga yang diajukan penjual dalam hal terdapat beberapa calon pembeli, maka calon pembeli dengan siapa kesepakatan tersebut akan dibuat, dipilih berdasarkan waktu yang tercantum dalam email yang berisikan persetujuan calon pembeli atas yang diminta penjual dan calon pembeli yang dipilih akan mendapat konfirmasi melalui email sedangkan calon pembeli yang lain akan mendapat email berisi pemberitahuan bahwa barang yang ingin dibeli sudah terjual.

(Hikmahanto Juana, 2003: 87)
Kekuatan pembuktian dokumen elektronik tersebut yang ditanda tangani dengan digital signature, dapat dikategorikan sebagai bukti tertulis, tetapi terdapat pengecualian, dokumen elektronik sebagai alat bukti hukum yang sah tidak berlaku untuk :

a. surat yang menurut Undang-Undang harus dibuat dalam bentuk tertulis; dan

b. surat beserta dokumenya yang menurut Undang-Undang harus dibuat dalam bentuk akta notaril atau akta yang dibuat oleh pejabat pembuat akta

Menurut Abdul Prasetyo, kekuatan pembuktian dokumen elektronik tersebut sama kekuatanya dengan akta otentik yang dibuat oleh Pejabat umum yang berwenang, seperti Notaris, hal ini berdasarkan pada Pasal 18 juncto Pasal 7 juncto Pasal 11 Undang-Undang Nomor 11 Tahun 2008 telah menegaskan transaksi elektronik yang dituangkan dalam dokumen elektronik mengikat para pihak yang menimbulkan hak dan kewajiban bagi masing masing pihak, asalkan ditanda tangani secara elektronik oleh para pihak sesuai dengan ketentuan perundangan yang berlaku. (Barkatullah, Abdul Prasetyo., Halim Teguh, 2005:34)

Menurut Salam Abdul, walaupun Dokumen elektronik dapat dijadikan alat bukti di dalam persidangan, yang merupakan perluasan hukum pembuktian di Indonesia setelah adanya Undang-Undang Nomor 11 tahun 2008, namun hanyalah mempunyai daya pembuktian sebagai akta di bawah tangan. (Salam, Abdul., 2008 : 2.)

Menurut Leanni Bharline, Dokumen elektronik tersebut walaupun sudah ditanda tangani dengan digital signature, tidak memenuhi syarat-syarat akta otentik yang ditentukan oleh Pasal 1868 KUH Perdata : " Suatu akta yang di dalam bentuk yang ditentukan oleh Undang-Undang, dibuat oleh atau di hadapan pegawai-pegawai umum yang berkuasa untuk itu di tempat di mana akta dibuatnya". Pasal 165 HIR dan Pasal 
$285 \mathrm{RBg}$ mengatur definisi tentang akta otentik yakni surat yang dibuat oleh atau dihadapan pegawai umum yang berkuasa akan membuatnya, mewujudkan bukti yang cukup bagi kedua belah pihak dan ahli warisnya serta sekalian orang yang mendapat hak dari padanya, yaitu tentang segala hal, yang tersebut dalam surat itu dan juga tentang yang tercantum dalam surat itu sebagai pemberitahuan saja, tetapi yang tersebut kemudian itu hanya sekedar diberitahukan itu langsung berhubung dengan pokok dalam akta itu. Di dalam UndangUndang Jabatan Notaris, menghadap kepada notaris, merupakan syarat mutlak untuk terjadinya perbuatan hukum tertentu, walaupun orang tersebut mewakili kepentingan orang lain, sehingga ketentuan Undang-Undang Nomor 11 Tahun 2008 bertentangan dengan Undang-Undang Nomor 30 Tahun 2004.

(Barkatullah, Abdul Prasetyo., Halim Teguh, 2005: 121 )

Akta otentik yang dibuat oleh notaris ada 2 macam bentuk :

1. akta relaas, adalah akta yang dibuat oleh notaris berdasarkan segala sesuatu yang dilihat, didengar, disaksikan atas peristiwa tertantu yang terjadi pada saat itu.

2. akta partij, adalah akta otentik yang dibuat dihadapan notaris yang didasarkan permintaan para pihak.

Walaupun ada satu bentuk akta otentik tersebut, ada pengecualian yaitu tidak menghadap ke notaris, tetapi notaris tersebut mendengar dan menyaksikan atas suatu peristiwa, sehingga menghadap ke notaris merupakan salah satu syarat yang utama untuk suatu akta otentik, bila dokumen elektronik tersebut mempunyai daya pembuktian yang sama dengan akta otentik, maka Undang-Undang Jabatan Notaris Nomor 30 Tahun 2004 haruslah direvisi, karena pada Pasal 1 ayat (7) akta notaris adalah akta otentik yang dibuat oleh atau di hadapan Notaris menurut bentuk dan tata cara yang di tetapkan dalam Undang-Undang ini.

Kekuatan pembuktian dari dokumen elektronik tersebut hanyalah akta dibawah tangan, dimana bentuk akta di bawah tangan dibuat dalam bentuk yang tanpa perantara atau tidak perantara atau tidak dihadapan pejabat umum yang berwenang, Mempunyai kekuatan pembuktian sepanjang para pihak mengakuinya atau tidak ada penyangkalan dari salah satu pihak. Jika salah satu pihak tidak mengakuinya, beban pembuktian diserahkan kepada pihak yang menyangkal akta tersebut, dan penilaian penyangkalan atas bukti tersebut diserahkan kepada hakim. Terdapat satu hal yang patut dipertimbangkan dalam pengakuan suatu dokumen elektronik yang ditandatangani dengan tanda tangan elektronik, yaitu keamanan suatu sistem dan keterlibatan dari orang terhadap sistem computer tersebut. (Rapin Mudiardjo, 2002).

Sedangkan eksistensi tanda tangan elektronik dalam sebuah dokumen elektronik harus diakui memiliki kekuatan hukum dan akibat hukum yang sama dengan tanda tangan pada dokumen tertulis lainnya. Hal ini berangkat dari pemahaman bahwa dokumen elektronik memiliki kekuatan hukum sebagai alat bukti dan akibat hukum yang sama sebagaimana dokumen tertulis lainnya. ${ }^{2}$

Tanda tangan elektronik yang menggunakan teknologi kriptografi asimetris, menggunakan dua buah kunci yaitu kunci privat dan kunci publik, maka terdapat suatu bukti bahwa dokumen elektronik tersebut merupakan kehendak sendiri dari pengirim. (Abdul Salam, 2008: 1 ).

Menurut Arianto Mukti Wibowo, agar tanda tangan elektronik pada suatu dokumen elektronik dapat mempunyai kekuatan pembuktian di pengadilan, maka harus mendaftarkan tanda tangan elektronik tersebut pada badan Certification Authority

2 lihat Penjelasan Rancangan Peraturan Pemerintah Tentang Tanda Tangan Elektronik 
\begin{tabular}{r|r|} 
V. Letsoin, Pengakuan Tandatangan Pada .................... & 58 \\
Jurnal Sasi Vol.16. No.3 Bulan Juli - September 2010 &
\end{tabular}

(CA), maka $C A$ tersebut dapat bertindak sebagai pejabat umum, sehingga dengan memanfaatkan infrastruktur yang diberikan $C A$ khususnya keamampuan untuk mengetahui kapan transaksi elektronik itu ditandatangani, maka transaksi elektronik yang ditanda tangani dipersamakan dengan akta otentik yang dibuat di depan pejabat yang berwenang.

Tanda tangan digital yang telah memperoleh sertifikat dari lembaga Certification Authority, maka akan lebih terjaminya otentikasi dari sebuah dokumen, dan tanda tangan digital sangat sulit dipalsukan dan berasosiasi dengan kombinasi dokumen dan kunci privat secara unik, apabila sudah melaksanakan ketentuan yang ditetapkan dengan peraturan PerundangUndangan yang terkait, maka sebenarnya tidak ada aturan Undang-Undang tersebut yang bertentangan. Seringkali Badan Negara yang berwenang mengeluarkan UndangUndang, antara satu Undang-Undang dengan Undang-Undang yang lain saling bertentangan satu sama lain, seperti UndangUndang Nomor 11 Tahun 2008, yang bertentangan dengan Undang-Undang Nomor 30 Tahun 2004, maka terhadap kasus yang aturan hukumnya bertentangan satu dengan yang lain, maka hakim berpatokan pada azas lex specialis derogate lex generalis, artinya Undang-Undang yang bersifat khusus menyampingkan Undang- Undang yang bersifat umum, dalam hal ini UndangUndang Nomor 11 Tahun2008 menyampingkan Undang-Undang Nomor 30 Tahun 2004. maka kekuatan pembuktian dokumen elektronik yang ditandatangani dengan tanda tangan elektronik sama dengan akta otentik. (Ronald Makaleo Tandiabang, Tomy Handaka Patria, Anang Barnea, 2005:1).

Berdasarkan pendapat-pendapat tersebut diatas, pengakuan dokumen yang telah ditandatangani dengan menggunakan digital signature, setelah dikeluarkan
Undang-Undang Nomor 11 Tahun 2008 tentang Informasi Dan Transaksi Elektronik, maka pengakuan dokumen elektronik yang ditandatangani dengan tanda tangan digital signature tersebut, merupakan perluasan dari pembuktian hukum acara perdata di Indonesia, sehingga seluruh transaksi elektronik dengan tanda tangan elektronik dapat dianggap sebagai akta, bahkan kekuatan pembuktiannya sama dengan akta otentik yang dibuat oleh pejabat yang berwenang. Kecuali yang ditentukan pada Pasal 5 ayat (4) Undang-Undang No. 11 tahun 2008 sebagaimana dimaksud pada ayat (1) tidak berlaku untuk:

a. surat yang menurut Undang-Undang harus dibuat dalam bentuk tertulis; dan

b. surat beserta dokumennya yang menurut Undang-Undang harus dibuat dalam bentuk akta notaril atau akta yang dibuat oleh pejabat pembuat akta.

Penjelasan Pasal 5 ayat (4) UndangUndang Nomor 11 Tahun 2008, bahwa surat yang menurut Undang-Undang harus dibuat dalam bentuk tertulis itu meliputi namun tidak terbatas pada surat berharga, surat yang berharga, dan surat yang digunakan dalam proses penegakan hukum acara perdata, pidana dan administrasi negara.

\section{PENUTUP}

\section{Kesimpulan}

Dokumen elektronik didalam hukum pembuktian di Indonesia, diakui esensinya setelah di atur di dalam Undang-Undang Nomor 11 Tahun 2008 tentang Informasi dan Transaksi Elektronik bahwa informasi elektronik/dokumen elektronik dan/atau hasil cetaknya merupakan alat bukti hukum yang sah, dan merupakan perluasan dari alat bukti yang sah sesuai dengan hukum acara yang berlaku di Indonesia hal tersebut berdasarkan ketentuan pada Pasal 5 ayat 2 UndangUndang Nomor 11 Tahun 2008. Seringkali 
V. Letsoin, Pengakuan Tandatangan Pada .....................

Jurnal Sasi Vol.16. No.3 Bulan Juli - September 2010

Badan Negara yang berwenang mengeluarkan Undang-Undang, antara satu Undang-undang dengan Undang-Undang yang lain saling bertentangan satu sama lain, seperti Undang-Undang Nomor 11 Tahun 2008, yang bertentangan dengan UndangUndang Nomor 30 Tahun 2004, maka terhadap kasus yang aturan hukumnya bertentangan satu dengan yang lain, maka hakim berpatokan pada azas lex specialis derogate lex generalis, artinya Undangundang yang bersifat khusus menyampingkan Undang-Undang yang bersifat umum, dalam hal ini Undang-Undang Nomor 11 Tahun 2008 menyampingkan Undang-Undang Nomor 30 Tahun 2004. Oleh karena itu, alat bukti menurut hukum acara di atas yang dibuat dalam bentuk informasi elektronik/dokumen elektronik, merupakan alat bukti yang sah menurut Undang-undang Informasi dan Transaksi Elektronik, sehingga seluruh transaksi elektronik dengan tanda tangan elektronik dapat dianggap sebagai akta, bahkan kekuatan pembuktiannya sama dengan akta otentik yang dibuat oleh pejabat yang berwenang, kecuali yang ditentukan pada Pasal 5 ayat (4) Undang-Undang Nomor 11 Tahun 2008 yaitu ketentuan mengenai Informasi elektronik dan/atau Dokumen Elektronik sebagaimana dimaksud pada ayat (1) tidak berlaku untuk :

a. Surat yang menurut Undang-undang harus dibuat dalam bentuk tertulis dan;

b. Surat beserta dokumennya yang menurut Undang-undang harus dibuat dalam bentuk akta notaril atau akta yang dibuat oleh pejabat pembuat akta.

\section{Saran}

1. Pemerintah dalam mengeluarkan suatu Undang-Undang hendaknya melihat

2. Undang-Undang yang lain yang saling berkaitan, sehingga antara satu UndangUndang dengan Undang-Undang yang lain tidak saling bertentangan satu dengan yang lain.
3. Pemerintah hendaknya segera mengesahkan Peraturan Pemerintah mengenai Tanda Tangan Elektronik dan Peraturan Pemerintah mengenai Sertifikasi Elektronik, sehingga ada aturan hukum lebih lanjut dari Undang-Undang Nomor 11 Tahun 2008.

4. Hendaknya Pemerintah dengan segera memberikan Lisensi kepada badan hukum sebagai lembaga Certification Authority, baik pemerintah maupun swasta, sehingga pelaksanaan transaksi elektronik, dengan dokumen elektronik sebagai perjanjian para pihak yang telah ditanda tangani secara elektronik, sehingga mempunyai kekuatan pembuktian yang sama dengan akta otentik didalam persidangan pada suatu pengadilan.

5. Menyiapkan infrastruktur dan sumber daya manusia yang baik untuk mendukung perkembangan transaksi komersial elektronik (e-commerce) di Indonesia.

\section{DAFTAR PUSTAKA}

\section{BUKU}

Barkatullah, Abdul Prasetyo., Halim Teguh, 2005, Bisnis E-commerce Studi Sistem Keamanan Dan Hukum Di Indonesia, Pustaka Pelajar, Jakarta Afandi,Ali., 2000, Hukum Waris Hukum Keluarga Hukum Pembuktian, Rineka Cipta, Jakarta

\section{PERATURAN}

Rancangan Peraturan Pemerintah Tentang Tanda Tangan Elektronik 
Undang-Undang Nomor 11 tahun 2008

Tentang Informasi Dan Transaksi Elektronik

\section{LAIN-LAIN}

Albarda, 1887, Sistim Informasi Untuk Kegiatan Promosi Dan Perdagangan, makalah pada seminar informasi ITB Bandung

Gema, Ario Juliano ., 2008, Apakah Dokumen Elektronik Dapat Menjadi Alat Bukti Yang Sah, www.Legalminded.com.

Juana, Hikmahanto., 2003, Legal Issues On E-commerce And E-contract In Indonesia, Jurnal Hukum Bisnis, volume 22.

Rapin Mudiardjo, 2008, Data Elektronik Sebagai Alat Bukti Masih Dipertanyakan, bebas.vlsm.org/v17/com/ictwatch/ paper/paper022.htm-15k

Tandiabang, Ronald Makaleo., Patria, Tomy Handaka, dan Barnea Anang, 2005, Otentikasi Dokumen Elektronik Menggunakan Tanda Tangan Digital, www.itb.go.id.

Wibowo,Arrianto Mukti., 1999, Kerangka Hukuum Digital Signature Dalam Electronic Commerce, amwibowo@caplin.cs.ui.ac.id.

Zamrony, Alat Bukti Baru Dalam Proses Peradilan, www.Zamrony.wordpress.com 